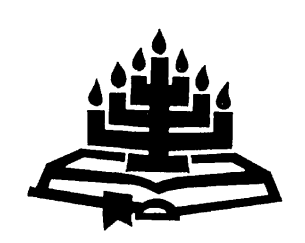

\title{
Die getuienis van Romeine 1:18-32 oor God se openbaring: 'n sintaktiese, stilistiese en gedagte-strukturele ontleding van die teks
}

\author{
F.P. Viljoen \\ Skool vir Bybelwetenskappe en Bybeltale \\ Potchefstroomse Universiteit vir $\mathrm{CHO}$ \\ POTCHEFSTROOM \\ E-pos: sbbfpv@puknet.puk.ac.za
}

\begin{abstract}
The evidence from Romans 1:18-32 about God's revelation.

A syntactical, stylistical and thought-structural analysis of the text

The question at stake in this article is to what extent people who have not heard the Gospel of Jesus can know God - according to Romans 1:18-32. In the ensuing argumentation the evidence from syntactical, stylistical and thought-structural analyses is investigated in search of answers to this issue. It becomes clear that it is crucial to take into consideration the function of this pericope within Paul's wider argumentation in attempting to interpret it. Before Paul can indicate that salvation is equally available to Jews and Gentiles, he must prove that all people are equally in need of it. His purpose is thus to draw up the indictment that everyone, non-Jews (Rom. 1:18/19-32) and Jews (Rom. 2:1-3:8) alike, are in the power of sin and subject to God's judgement. Paul marshals the evidence against everyone. The way in which Paul demonstrates this is by dividing the human race into two sections and accusing every one of them. He begins by reminding each group of their knowledge of God and His goodness. He then confronts them with the fact that they have not lived in accordance with their knowledge of God. Instead, they have deliberately suppressed it by continuing to live in unrighteousness. They are therefore inexcusably guilty. Nobody can plead ignorance. To interpret Paul as if it would be possible to attain saving faith without the Gospel demonstrates a misunderstanding of Paul's argumentation.
\end{abstract}


Opsomming

Die getuienis van Romeine 1:18-32 oor God se openbaring.

'n Sintaktiese, stilistiese en gedagte-strukturele ontleding van die teks

Die vraagstuk aan die orde in hierdie artikel is in hoeverre mense, wat nie die evangelie van Jesus Christus gehoor het nie, God kan ken volgens Romeine 1:18-32. In die daaropvolgende beredenering word die getuienis van sintaktiese, stilistiese en gedagtestrukturele analises ondersoek om vas te stel watter lig dit op die vraagstuk kan werp. Dit blyk dat dit van wesentlike belang is om die funksie van die betrokke perikoop binne die breër konteks van Paulus se argumentasie in ag te neem, ten einde die perikoop te kan interpreteer. Voordat Paulus kan aantoon dat verlossing vir Jode en nie-Jode beskikbaar is, moet hy eers bewys dat hulle almal die verlossing nodig het. Hy voer aan dat sowel die nie-Jode (Rom. 1:18/19-32) as die Jode (Rom. 2:1-3:8) gebuk gaan onder die mag van die sonde en die oordeel van God verdien. Paulus stapel getuienis teen albei groepe op. Die manier waarop Paulus dit doen, is deur die mensdom in twee groepe te verdeel en hulle dan die een na die ander te beskuldig. Hy begin deur hulle te herinner aan hulle kennis van God en aan sy goedheid. Hy konfronteer hulle daarna met die feit dat hulle nie ooreenkomstig hierdie kennis geleef het nie. Hulle het hierdie kennis moedswillig onderdruk deur voort te gaan om in ongeregtigheid te lewe; daarom is hulle onverskoonbaar skuldig. Niemand kan onskuldig pleit nie. Om Paulus te interpreteer asof dit moontlik sou wees om die saligmakende geloof sonder die evangelie te verkry, openbaar ' $n$ verkeerde verstaan van die hele argumentasie van Paulus.

\section{Inleiding}

Die vraagstuk aan die orde in hierdie artikel is hoeverre mense God kan ken alleenlik op grond van God se skepping en die onderhouding van die natuur. Dié vraagstuk kom veral na vore op grond van bevindings van Kruger (2000a en 2000b) oor die openbaring van God aan diegene wat nie die boodskap van die Bybel gehoor het nie.

Die doel van hierdie artikel is om te omskryf watter getuienis sintaktiese, stilistiese en gedagte-strukturele ontledings van Romeine 1:18-32 kan lewer oor die verhouding tussen die skeppingsopenbaring en die kennis van God. Hierdie artikel vorm deel van 'n omvattende studie van verskeie navorsers en fokus daarom op hierdie beperkte deel van die vraagstuk.

Die tekstuele konteks waarbinne 'n perikoop voorkom, dra by tot die betekenis daarvan. Gevolglik word die posisie van Romeine 1:18-32 binne die konteks van die hele Romeinebrief aanvanklik ondersoek. Daarop volg 'n sintaktiese struktuurontleding van die betrokke perikoop met kommentaar daarby. Vir die sintaktiese struktuurontleding word 
aangesluit by die metode soos deur Janse van Rensburg (1980) ontwikkel. Dié metode dui die relasie tussen elke sintaktiese komponent by wyse van lynverbindings en pyle aan. In hierdie artikel word egter nie die detail van al die relasies aangetoon nie. Die veronderstelling is dat die leser die mees voor die hand liggende relasies self kan identifiseer. Daarbenewens word groter klem gelê op die sintaktiese verhouding wat kan lig werp op die vraagstuk wat ondersoek word. Vanuit die sintaktiese ontleding word stilistiese patrone geïdentifiseer en kortliks bespreek hoe hierdie patrone kan meehelp om die perikoop te verstaan. Hierop volg 'n gedagtestruktuur-ontleding en 'n bespreking daarvan. Vir die ontleding van stilistiese patrone en gedagtestruktuur-ontleding word aangesluit by die metodes van Coetzee (1988:19-37) en Jordaan (1988:70-80).

\section{Tekstuele konteks van Romeine 1:18-32}

Met sy inleiding (1:1-17) het Paulus in $1: 15$ gekom tot sy verklaring dat hy hom gedronge voel om die evangelie ook in Rome te verkondig. Hy sluit af met 'n kernagtige omskrywing van die inhoud, werking en krag van die evangelie (1:16-17). Vanaf $1: 18$ gaan hy voort om die noodsaak en inhoud van die evangelie met verskeie hoofdele te verduidelik (Du Toit, 1989:16; Greijdanus, 1933:104; Lekkerkerker, 1974:43-54), want daar is "buiten het Evangelie geen zaligheid" (Ridderbos, 1959:40).

In sy eerste hoofdeel begin hy met die omskrywing van die skuld, verdorwenheid en verlorenheid van alle mense, heidene sowel as Jode (1:18-3:20). Paulus gebruik die woord ásı kía (ongeregtigheid) herhaaldelik om die mislukking van die mens aan te toon (1:18 twee keer, 1:29, $2: 8$ en 3:5). Die dubbele gebruik van die woord in $1: 18$ vorm as 't ware die opskrif van die hele gedeelte (Dunn, 1988:51). Dit moet die leser onder die indruk bring van die haglike en reddelose situasie van alle mense (Pelser, 1989:30). Coetzee (1986:10) omskryf hierdie hoofdeel as die klagstaat, naamlik "daar is niemand regverdig nie, selfs nie een nie". Alle mense, Jode en nie-Jode is skuldig aan die dood (Du Toit, 1989:18; Moores, 1995:37). Paulus stel in 1:18-3:20 die probleem om vanaf 3:21 by die oplossing uit te kom (Porter, 1994:210).

In 1:18-32 is 'n beskrywing van die ongeregtigheid (skuld) van die heidene, wat God se openbaring in die skepping het, maar Hom nie erken nie. ${ }^{1}$ Daarna (2:1-3:8) volg 'n beskrywing van die ongeregtigheid (skuld) van die Jode, wat ook die openbaring van God se wet het, maar dit nie onderhou nie. In 3:9-20 word die ongeregtigheid van alle mense

1 Romeine 1:18 sou na Jode en nie-Jode kon verwys. Wat vanaf vers 19 geskryf staan, stem egter ooreen met die beskouing wat Jode van nie-Jode en hulle sondes gehad het. 
saamgevat; daarom het niemand enige verweer teen die oordeel van God nie.

Uit hierdie hoofdeel blyk dit onmiskenbaar dat almal aan die oordeel van God onderworpe is (vgl. 3:19). Vir niemand is daar 'n ander manier om gered te word as deur die evangelie nie. Dit is 'n kenmerkende tema in die prediking van Paulus (vgl. Floor, 1982:79). Die evangelie behels die louter genade van Christus se versoeningswerk. Die evangelie is noodsaaklik. Daarsonder is die hele wêreld heeltemal verlore en sal dit in die ewige oordeel versink (Morris, 1992:72). Hieruit word dit duidelik waarom dit noodsaaklik is dat Paulus ook Rome moet besoek om die evangelie te verkondig.

\section{Sintaktiese struktuur}

\subsection{Ontleding}

Ten einde die sintaktiese skakel van Romeine 1:18 met die voorafgaande te verklaar, is dit nodig om die gegewens vanaf 1:15 weer te gee. Daaruit blyk dat die perikoop wat vanaf 1:18-32 strek, 'n motivering is van Paulus se verlange om ook in Rome die evangelie te verkondig (1:15). Na Paulus se stelling in 1:15 volg motiverings daarvoor, elk met ráp (want) ingelui.

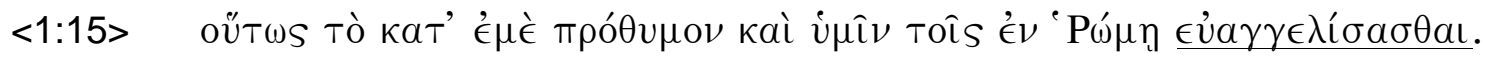

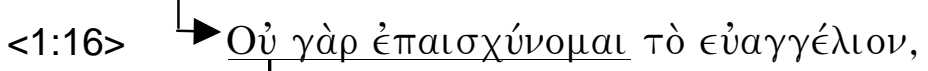

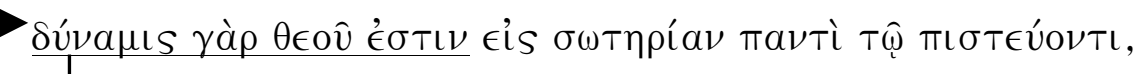

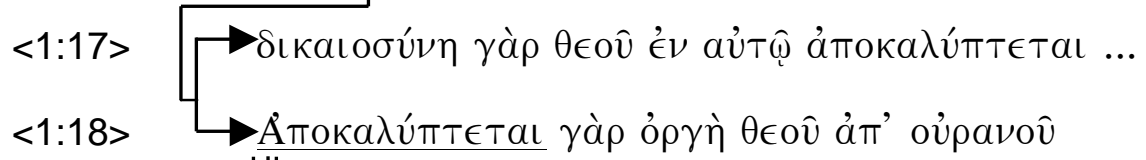

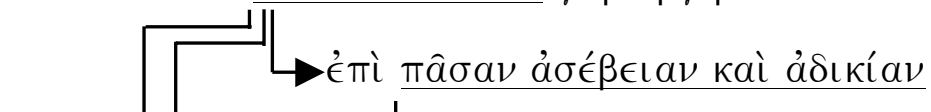

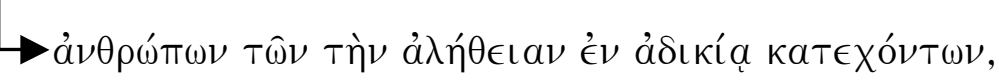

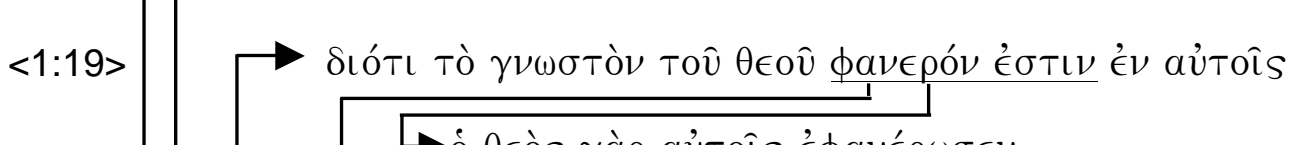

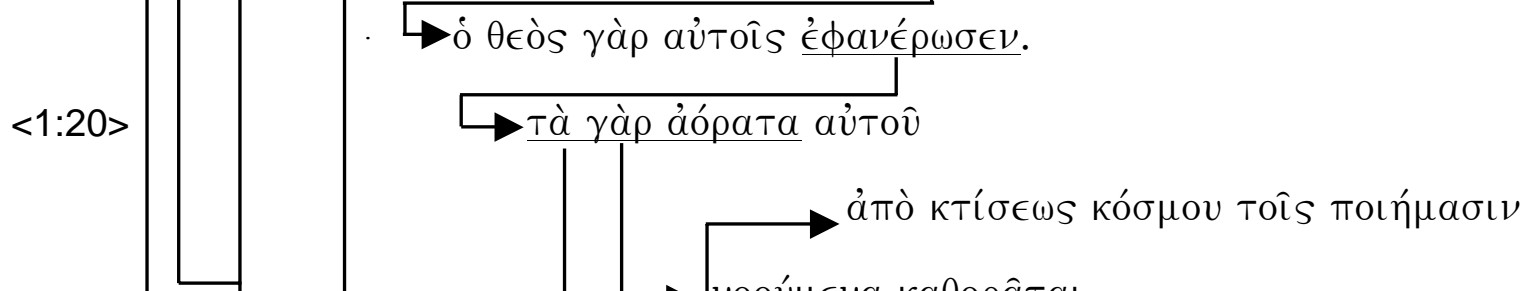

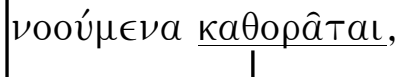

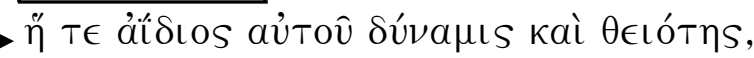

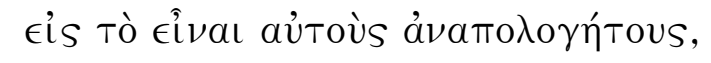




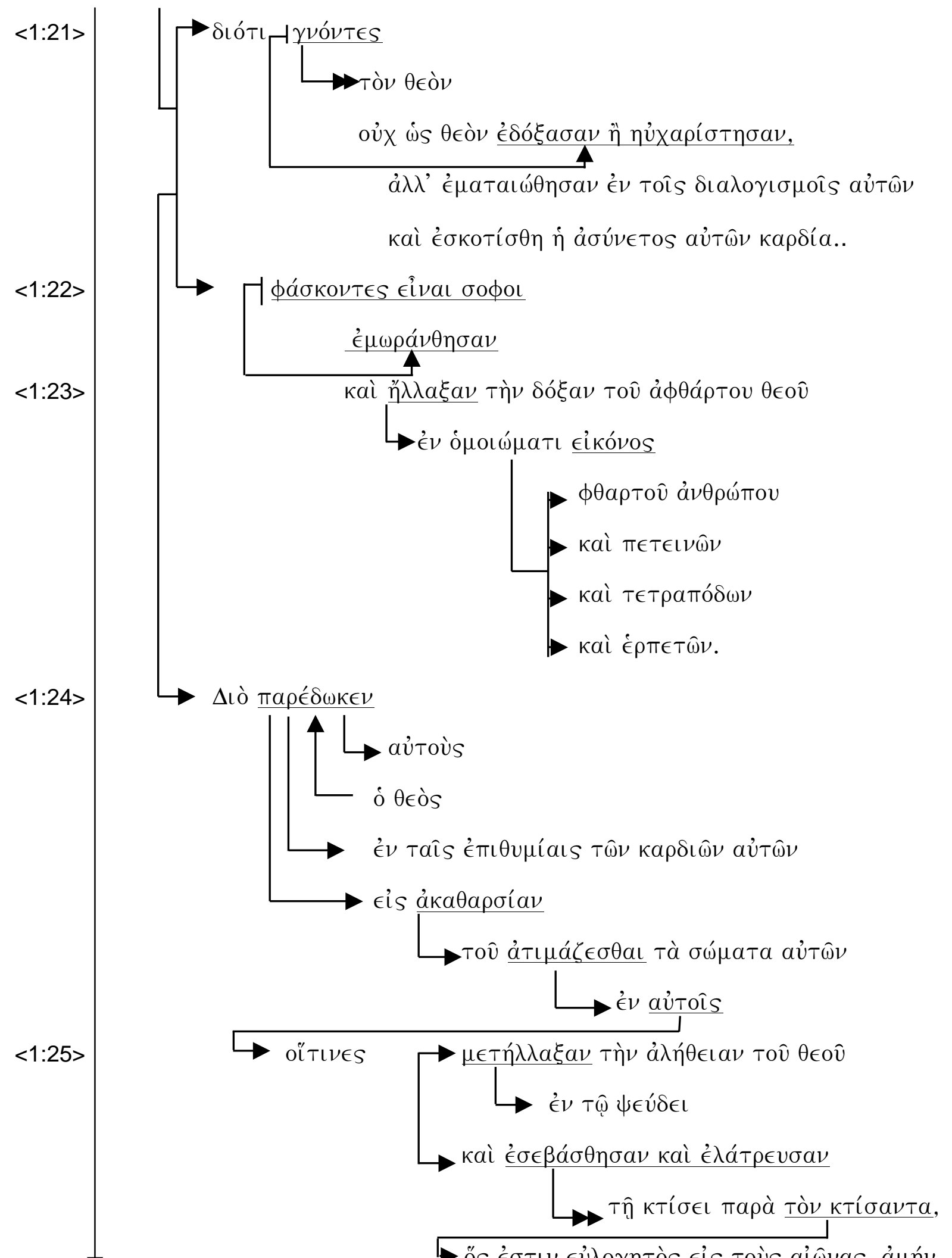




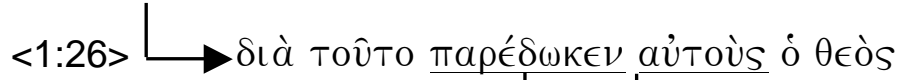

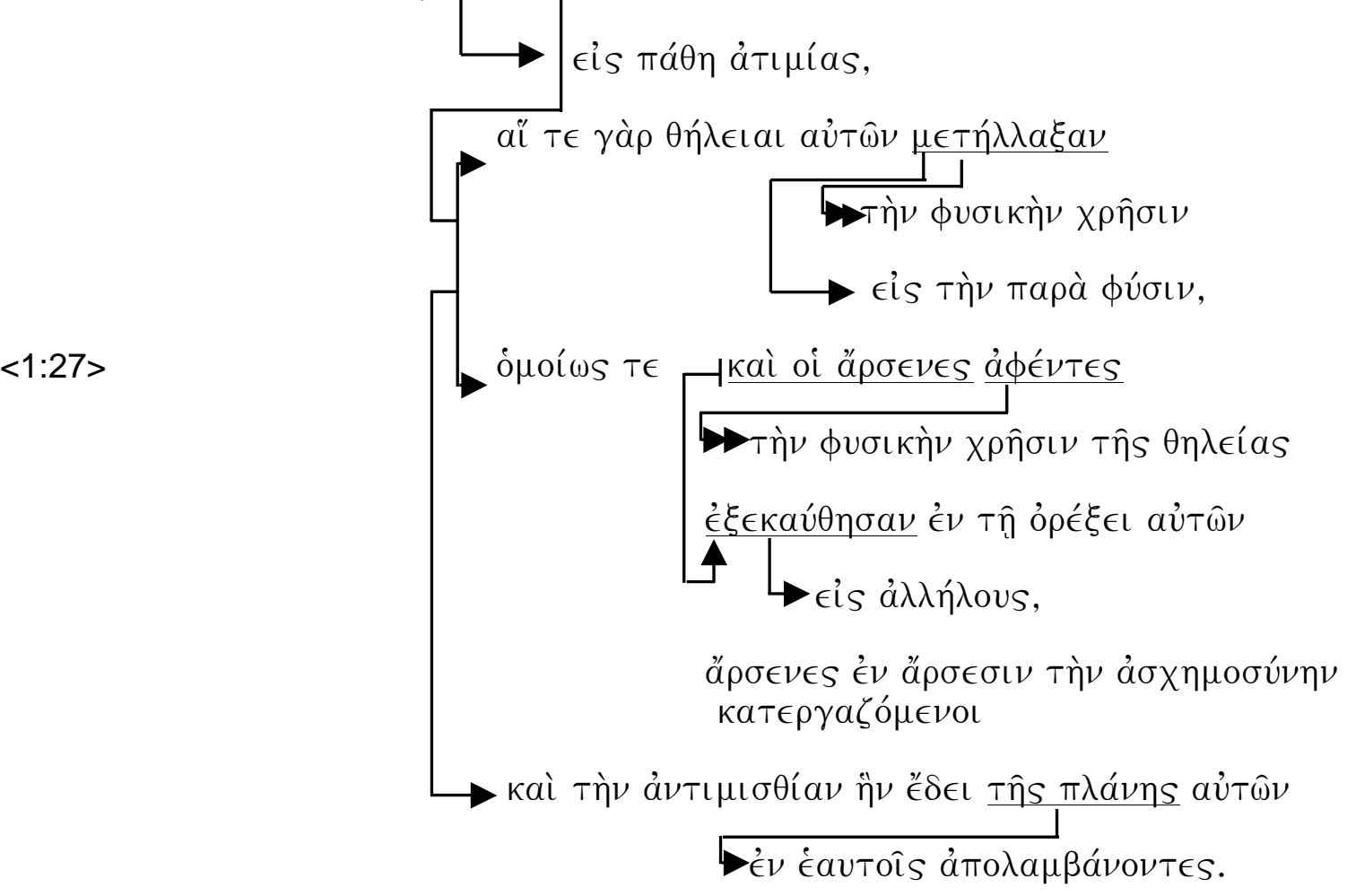

$<1: 28>$

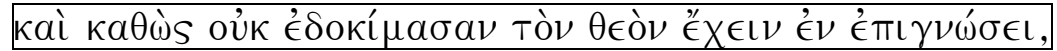

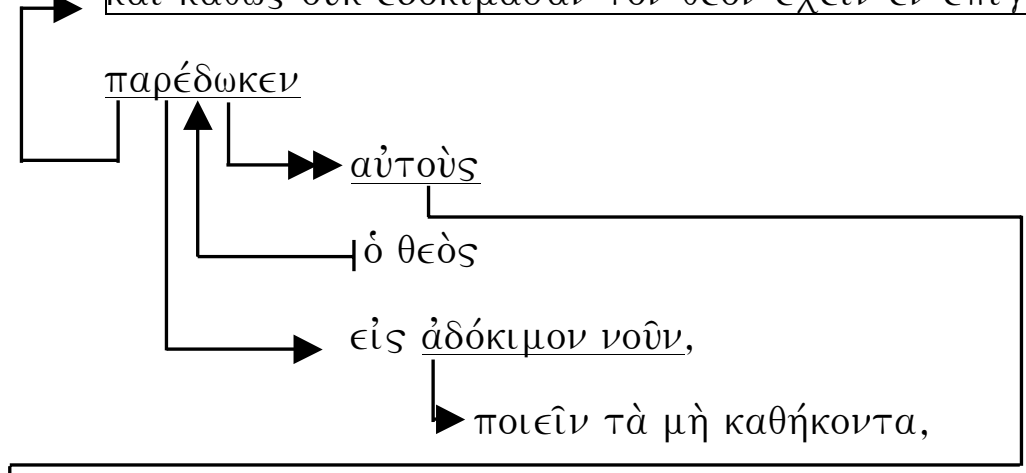

$<1: 29>$

$<1: 30>$

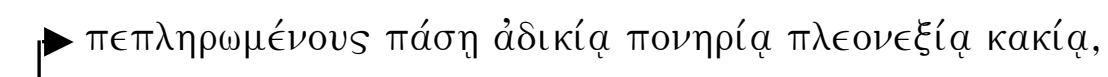

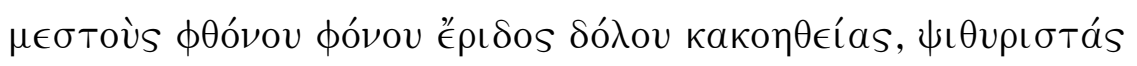

$<1.30>$

$<1: 31>$ $<1: 32>$

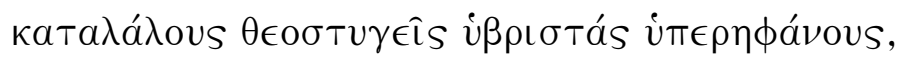

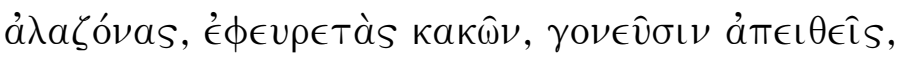

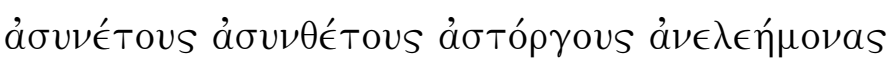

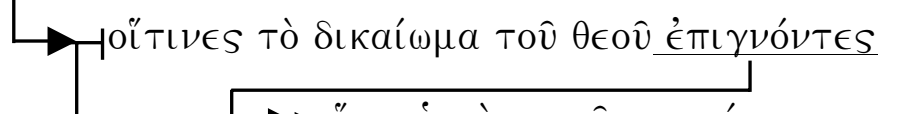

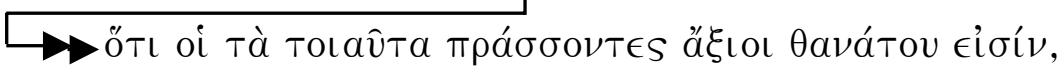

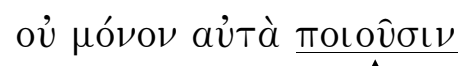

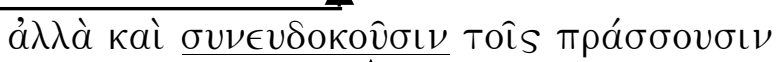




\subsection{Kommentaar}

\section{Vers 18:}

Die woord $\gamma$ à $\rho$ (want) waarmee vers 18 begin, is die vyfde van 'n ketting van redegewende frases wat met $\gamma$ à $\rho$ ingelui word om te verduidelik waarom Paulus hom gedronge voel om die evangelie ook in Rome te verkondig (vgl. onder andere Morris, 1992:75):

- Want hy skaam hom nie oor die evangelie nie (vers 16a);

- Want die evangelie is ' $n$ krag van God tot saligheid vir elkeen wat (dit) glo (vers 16b);

- Die krag van die evangelie is daarin geleë dat die geregtigheid van God enersyds daarin geopenbaar word (vers 17) en andersyds dat die toorn van God uit die hemel geopenbaar word (vers 18).

Die $\gamma$ à $\rho$-frase van vers 18 is sintakties parallel aan die $\gamma a ̀ \rho$ (want)-frase van vers 17. Vers 17 en 18 bied onderskeidelik die twee skerp kontrasterende redes waarom die evangelie 'n krag van God is vir elkeen wat glo (Dunn, 1988:54). In vers 17 word die geregtigheid van God beskryf in terme van die vryspraak wat God bied. Die geregtigheid van God mag egter nie vervlak word tot "een alles-maar-vergevende barmhartigheid Gods" nie (Lekkerkerker, 1974:55). Die geregtigheid van God bevat ook 'n oordelende kant. God se toorn is nie 'n corpus alienum in die liefde van God nie. Dit hoort daarby as die "spits van de vlam zijner liefde" (Gunning, 1868:165). In vers 18 word God se geregtigheid as die openbaring van God se toorn genoem. So lig Paulus die voorafgaande rede toe by wyse van die teendeel (Ridderbos, 1959:40).

Die rede wat in vers 18 gegee word, is dat die toorn van God reeds van die hemel af oor die goddeloosheid van die mense geopenbaar word

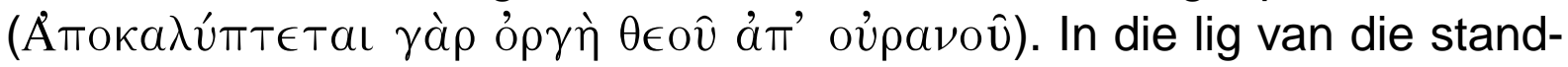
punt van Kruger (2000a) dat God ook kenbaar is uit sy werke in die skepping en die onderhouding daarvan, moet die vraag gestel word hoe mense die openbaring van God se geregtigheid en toorn te wete gekom het. Sou dit vir hulle sonder meer duidelik wees uit hulle "natuurlike" rede? In die lig van vers 17 en 18 alleen is dit nie moontlik om 'n antwoord te vind nie. Die gedagtegang vanaf vers 19 bied verdere lig, met die gevolg dat die vraagstuk later weer aan die orde sal kom.

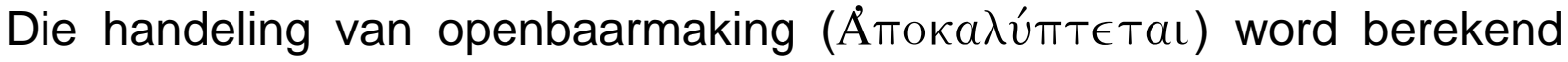
herhaal om die kontras met 1:17 te toon. In 1:18 word die woord nader verklaar deur 'n bepaling wat met $\epsilon$ 't (oor) ingelui word. Uit hierdie bepaling blyk dat God se toorn sy heilige reaksie is op die opstand teen

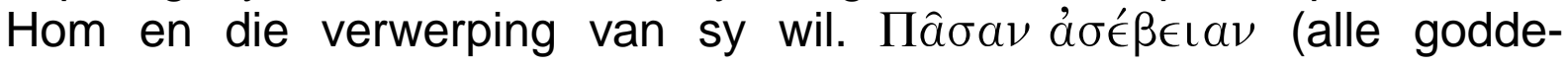


loosheid) en ásı kíav (ongeregtigheid) word met die voegwoord kaì (en) neweskikkend aan mekaar gebind. Goddeloosheid verwys na al die vorme van opstand teen en veragting van God, terwyl ongeregtigheid die vertrapping van God se reg deur 'n verkeerde lewenstyl in die oog het (Jonker, 1967:35). Hierdie oortredings word nader verklaar deur die

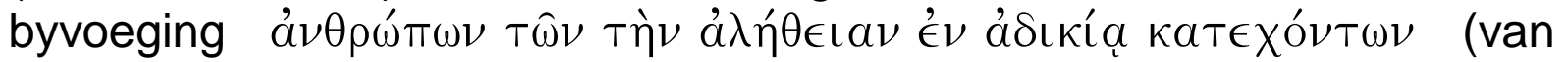
die mense wat in ongeregtigheid die waarheid onderdruk), waardeur die bron beskryf word waaruit die oortredings voortkom. Die waarheid is nie onbekend nie, maar word doelbewus onderdruk. Dat die mens goddeloos is, is nie die gevolg van onskuldige onkunde nie. In hierdie woorde eggo die Adam-narratief van Genesis 2 en 3 (Dunn, 1988:53).

Die mense na wie verwys word, sou na mense in die algemeen kon wees. Die beskrywing van hulle goddeloosheid in die hieropvolgende verse pas ook inderdaad by die heidene van die destydse Rome. Boonop word in Romeine 2 duidelik onderskei tussen die oordeel oor Jode wat onder die wet lewe teenoor die heidene wat sonder die wet lewe. Terugskouend vanuit Romeine 2 blyk dit dat die apostel in hoofstuk 1 spesifiek die heidene in die oog gehad het.

Die dreiging van die toorn bied ' $n$ verdere verduideliking van die rede waarom Paulus homself gedronge voel om sy boodskap van genade in Rome te gaan verkondig (vers 15). Dit is 'n voortsetting van die redegewende sinne van die vorige twee verse (vers 16 en 17). Die "want" van vers 18 wil nou sê: "Waar sake so staan, moet ek beslis ook na Rome [gaan], aangesien ook dáár goddeloosheid en ongeregtigheid in die lewe van mense heers, waarvan hulle alleen langs die weg van hierdie boodskap verlos kan word" (Jonker, 1976:35). Paulus se gedagtegang herinner aan Jesus se ywer toe Hy op die ongeregtigheid in die tempel afgekom het (Joh. 2:15) en Paulus wat deur die afgodsbeelde in Athene aangespoor is om die evangelie te verkondig (Hand. 17:16).

\section{Vers 19:}

Vers 19 word met die redegewende voegwoord SıóTı (omdat) ingelui om die eerste van twee redes te gee waarom God se toorn geopenbaar word (vers 18) (Vers 21 begin met dieselfde voegwoord en staan waarskynlik neweskikkend tot die eerste rede; vgl. Greijdanus, 1933:108; Ridderbos, 1959:42.) Dit wat van God geken kan word, is in hulle geopenbaar ( verklaar Paulus hoe dit wat kenbaar is, vir hulle kenbaar kan wees met

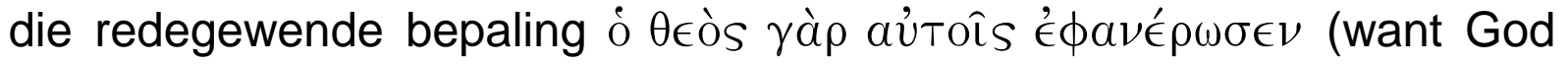
het dit aan hulle geopenbaar). 
Hierdie vers kan aanleiding gee tot kontroversie - soos in die argumente van Kruger (2000). Navorsers oor 'n breë front het hierdie vraagstuk al by herhaling beredeneer, en kom tot die gevolgtrekking dat Paulus nie hier oor die reddende kennis van God skryf nie. "The context is concerned with the condemnation of the Gentile world, not its salvation" (Morris, 1992:78). Paulus redeneer immers oor die noodsaaklikheid van die verlossingswerk van Christus! "He was not facing the question whether there was enough in the revelation for them to be saved ... we should not torture Paul's words into giving answer to a question he is not facing" (Morris, 1992:79). Young (2000:696) kom tot dié gevolgtrekking: "All persons have a vague, unthematic awareness of God ... the recognition of creaturely finitude awakens a faint, intuitive awareness that there is something beyond". Barth (1968:45) sluit by Aquinas aan en toon aan dat hier nie sprake is van ware kennis nie, maar slegs kennis van onkunde: "We know that God is He whom we do not know, and that our ignorance is precisely the problem and the source of our knowledge".

\section{Vers 20:}

Hierdie openbaring van God (vers 19) word nader omlyn deur 'n

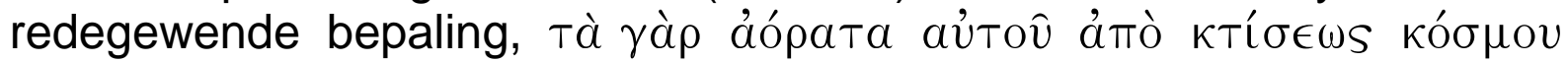

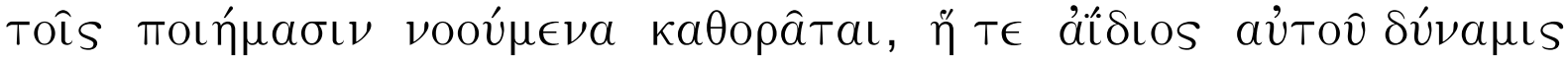

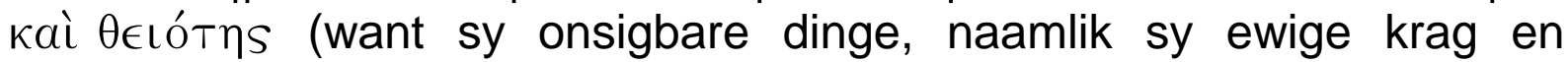
goddelikheid, kan van die skepping van die wêreld af in sy werke duidelik verstaan word). Vanaf die skepping lewer God se dade 'n onontkenbare getuienis van die onsigbare dinge van God. "Zij blijven geconfronteerd met Gods eeuwige kracht en goddelijkheid" (Ridderbos, 1959:43).

$\mathrm{Na}$ die redegewende bepaling (vers 19b en 20a) by "wat van God geken kan word, geopenbaar is", volg dan die voorsetsel $\epsilon$ is met die infinitief-

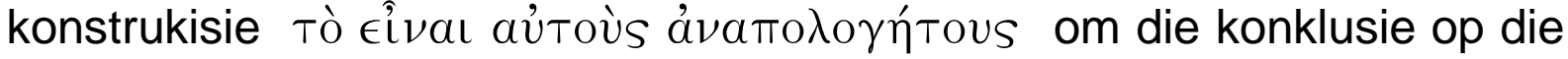
voorafgaande argument (vers 19 en 20a) te gee (met die gevolg dat hulle sonder verontskuldiging is). Die infinitiefkonstruksie sou ook doel kon uitdruk, maar binne die gedagtegang lyk dit minder waarskynlik. ${ }^{2}$

Vers 19 en 20 plaas ons midde in die debat wat Kruger (2000a en 2000 b) voer oor die moontlikheid van Godskennis buite die geskrewe Woord om. 'n Vraag wat hiermee saamhang, is of daar in nie-Christelike godsdienste ook 'n sekere Godskennis bestaan. Die antwoord op laasgenoemde vraag sou bepalend wees vir gesprekke oor die verhouding tussen die Christendom en ander godsdienste. Om dié vraag op die

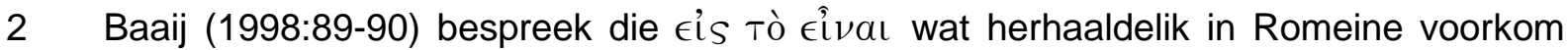
en toon hoe dit dikwels as doelkonstruksies dien. In hierdie konteks lyk dit egter onwaarskynlik. 
spits te dryf kan die vraag gestel word: Hoedanige Godskennis is moontlik op grond van die natuur en geskiedenis, buite die openbaring van God in Jesus Christus om? Sou dit ook heilskennis kon impliseer?

Dit wil voorkom asof die apostel 'n entumemiese argument gebruik deur algemeen aanvaarde voorkennis te veronderstel (vgl. Moores, 1995:46). Sy eerste lesers het oor 'n verwysingsraamwerk beskik wat nie noodwendig vir die leser na eeue meer voor die hand liggend is nie. Blykbaar gaan Paulus hier terug op 'n algemene, Joodse leertradisie met enkele spore van beïnvloeding deur die terminologie van die Stoa (Lekkerkerker, 1974:61). Dat God op grond van sy werk geken kan word, was nie vir die Jode 'n vreemde gedagte nie (bv. Ps. 8 en 19). In Job 38 en 39 word beskryf hoe God Job opgeroep het om Hom uit sy skepping te ken: "Waar was jy toe Ek die aarde se fondamente gelê het?..." (Job 38:4) (vgl. onder andere Young, 2000:697).

Dit is ook 'n moontlikheid dat Paulus verwys na die apokriewe boek van die Wysheid van Salomo (vgl. Dunn, 1988:57; Stott, 1994:70). Hoofstuk 13 en 14 van dié boek is 'n Hellenisties-Joodse polemiek teen heidense afgodsdiens. Sanday en Headlam (1902:51) gee 'n tabel om die moontlike parallelle tussen Romeine en die Wysheid van Salomo aan te toon. Die Wysheid van Salomo verwys na heidene wat God nie erken nie, hoewel Hy Hom geopenbaar het in sy werke: "From the good things that are seen they gained not power to know Him that is" (13:1); die sonde en dwaasheid van die heidendom: "They ... called then gods which are works of men's hands" (13:10); "the worship of those nameless idols is a beginning and cause and end of every evil" (14:27); "the confusion of sex ... disorder in various social ills" en die gevolgtrekking dat diegene wat nie daarin slaag om God op grond van sy werke te vind nie "are not to be excused" (13:8). Owen (1959:138) waarsku egter teen 'n regstreeks parallel tussen Romeine 1 en die Wysheid van Salomo deur duidelike verskille daartussen aan te toon. Die Wysheid (13) handel oor kennis wat moontlik is, maar wat nie verkry is nie. Romeine 1 handel oor kennis wat moontlik is, wat ook wel verkry is, maar wat dan in ongeregtigheid onderdruk is (vers 18).

'n Kosmologiese godsbewys kom by talle Griekse filosowe voor. Volgens Plato wys die skoonheid van die wêreld na die god daarvan. Aristoteles lê 'n verband tussen die beweging in die wêreld en die beweger daaragter. Die Stoïsyne praat oor die onsigbaarheid van God, terwyl Hy uit sy werk geken kan word. Volgens Michaelis $(1978: 323,368)$ en Young (2000:697) word God sigbaar in sy werke - gedeeltelik op rasionalistiese wyse en gedeeltelik op panteïstiese wyse. Wat blykbaar by die Griekse filosowe ontbreek het, is die idee dat 'n god die wêreld ex nihilo geskep het (Owen, 1959:138). Die besonderhede in Romeine 1 klop hiermee. 
Dat God onsigbaar en ewig is, was vir die Platoniste vanselfsprekend selfs die lede van die Homeriese pantheon is as onsterflik beskou. Dat gode oor krag beskik het om vrugbaarheid in die natuur te bewerk en welsyn aan toegewydes te verseker, was algemeen aanvaar. Goddelike geregtigheid waardeur oortreders gestraf is, was 'n sentrale element in die Griekse en Romeinse vroomheid. Dat God egter die Skepper is, en die wêreld sy skepping, en dat die skepping daarom aan Hom eer verskuldig is, het nooit deel gevorm van heidense godsdienste nie (Dunn, 1988:58). Cook (1994:494-517) toon aan hoe Paulus in 'n beperkte mate by die beskouing van die Hellenistiese filosofie aansluit met die doel om sy gehoor te oortuig. "Any claim that God could be perceived in the cosmos might have been welcomed by the dominant culture" (Cook, 1994:516) en "Paul developed his theology in Romans 1:20 using some of the most powerful tools hellenistic culture could provide him" (Cook, 1994:517). Paulus huiwer egter nie om ook aan te toon dat hierdie godsbesef die heidene gebring het by 'n verkeerde godsbeeld - wat hulle sonder verontskuldiging laat.

Owen (1959:137) vergelyk Romeine 1 met Handelinge 14:15-17 en 17:23 om hierdeur lig te werp op die vraagstuk van Romeine 1. Heidene was ook bewus van god(e) en het selfs hulle afhanklikheid van god(e) erken, maar hulle het nooit sover gekom as om God as Creator mundi te erken nie. Hulle beperkte kennis van God dien bloot as 'n "point of contact" (Owen, 1959:142) vir die evangelie. Die evangelie vergroot hulle kennis van God as Skepper, die persoonlike God van liefde, die Vader van Jesus Christus. Hierdie kennis ontbloot die daad van ongeregtigheid en goddeloosheid waaruit die onderdrukking van die waarheid voortspruit.

Paulus sluit dus aan by dit wat destyds algemeen deur die heidense godsdienste en filosowe aanvaar is. Hulle besit inderdaad 'n bewustheid van God, maar baie vaag en verwronge. Sonder God se besondere openbaring wat saamtrek in Jesus Christus, bly hulle kennis gebrekkig.

Die Sinode van die Deutsche Evangelishe Kirche wat in Mei 1934 in Barmen gehou is, het ook aan hierdie vraagstuk aandag gegee (Von Campenhausen et al., 1957:875). Dié sinode het die vraagstuk oor "natürliche Religion und Theologie" ter tafel geneem. Die vraag is gestel of 'n mens "van nature", dit wil sê uit sy eie en buite Jesus Christus om, God sou kon ken. Die eerste tese van Barmen lui:

Jezus Christus, zoals Hij ons in de Heilige Schrift betuigd wordt, is het éne Woord Gods dat wij te horen, dat wij in leven en sterven hebben te vertrouen en te gehoorzamen. Wij verwerpen de valse leer, als zou de kerk als bron voor haar verkondiging buite en naast 
dit éne Woord Gods ook nog andere gebeurtenissen en machten, gestalten en waarheden als Gods openbaring erkennen (in Lekkerkerker, 1974:62).

Hierdie sinode verwerp die standpunt dat 'n mens God op grond van die natuurlike, menslike rede kan ken. Tog het die diskussie oor Godskennis buite die Bybel om steeds nie tot rus gekom nie.

Vanuit die sintaktiese konteks van Romeine 1:19 en 20 blyk dit dat Paulus nie verwys na ' $n$ bekendstelling van God in die werklikheid van die wêreld en dat sy openbaring in Jesus Christus dan bykomstig is nie. In die voorafgaande verse praat die apostel oor die evangelie as krag van God (Rom 1:16). Vanuit hierdie stelling oor die evangelie gaan Hy voort om oor die openbaring van God se geregtigheid en toorn te skryf. Daar is 'n sekere kennis van God in alle mense ingeplant. Die probleem is egter dat hulle dit nie besef of erken nie (Dunn, 1988:58). Dit moet vir hulle gesê word vanuit die evangelie, want hulle het die kennis van die waarheid onderdruk (vers 18) en sodoende die kennis van God verdring. Daarom is hulle sonder enige verontskuldiging.

Luther gebruik in hierdie verband die voorbeeld van die heidense seemanne in die boek Jona. Hulle het wel besef dat daar 'n God is, selfs dat Hy 'n helper is in nood, maar tog het hulle Hom nie geken nie (Luther, 1927 [1515/1516]:632; Bornkamm, 1948:44). Calvyn skryf oor hierdie seemanne dat hulle wel tot God geroep het, maar op 'n bygelowige manier, elkeen tot sy eie god. In werklikheid het hulle algemene kennis van God gelei tot 'n verskriklike bron van afgodery en bygeloof (Calvyn, 1849 [1539]:73). Calvyn skryf wel in sy Institusie (I, 3) van 'n "kennis Gods van nature in de geest der mensen ingeplant" en ook "dat in de menselijke geest een besef der Godheid is ingegrift dat nimmer vernietigd kan worden". Calvyn se bedoeling met hierdie woorde word dan duidelik as hy later wys op die "halsstarrigheid der goddelozen die, hoe verwoed ze ook worstelen, zich toch niet kunnen loswarren uit de vrees voor God" (I, 3, 3). In I, 4 skryf Calvyn dat die heidene hierdie kennis van God nie wil erken nie "... door hardnekkigheid ten onder gehouden"; en die "onbestendige en ronddolende mening over de godheid is in wezen een niet-kennen van God".

Die implikasie is dat God Homself wel kenbaar maak by alle mense, maar dat goddelose mense hierdie kennis onderdruk en verwerp. In die lig van hierdie verklaring pas Paulus se woorde: “... daarom is hulle sonder enige verontskuldiging" (Rom. 1:20).

Die apostel bou die prediking van die evangelie nie op 'n hipotese van 'n semen religionis nie. Nog minder is hy geïnteresseerd in die vraag of die mens God uit homself sou kon ken. Hy praat in die omgekeerde 
volgorde. Vanuit die evangelie van die Verlosser praat hy oor die Skepper en oor 'n besef van God se goedheid om die mens des te meer in 'n staat van beskuldiging te stel. Dit moet aan die mens verkondig word dat hy God nie as God verheerlik nie en daarom doemwaardig is (Moores, 1995:46).

\section{Vers 21:}

Vanaf vers 21 volg die tweede rede waarom God se toorn geopenbaar word (vers 18). Soos met die eerste rede (vers 19 en 20) word hierdie rede ook met $\delta ı$ ó ı (omdat) ingelui. Hierdie rede val in twee dele uiteen

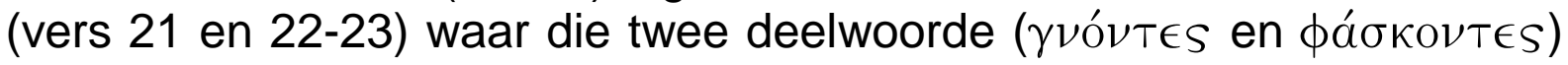
neweskikkend ten opsigte van mekaar gestel is. In die eerste been van die rede (vers 21) word gestel dat in weerwil daarvan dat God bekend is,

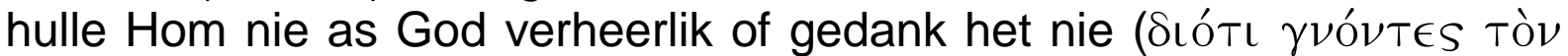

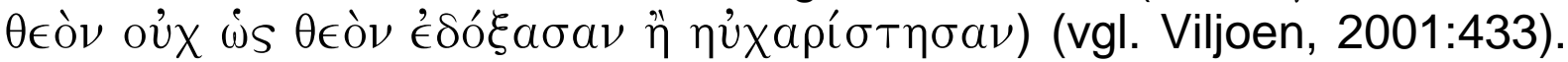
Hulle het egter die teendeel gedoen (die voegwoord $\alpha \lambda \lambda$ ' [maar] stel die teendeel). Omdat hulle die waarheid onderdruk het, het hulle in hul eie leuen verstrik geraak. Hulle het dwaas geword in hulle oorlegginge

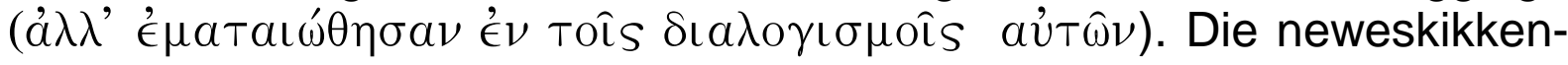
de voegwoord kai (en) lui die verdere gevolg van hulle dwase oor-

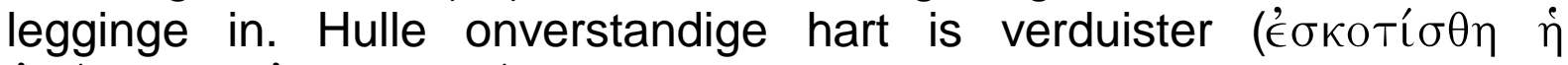

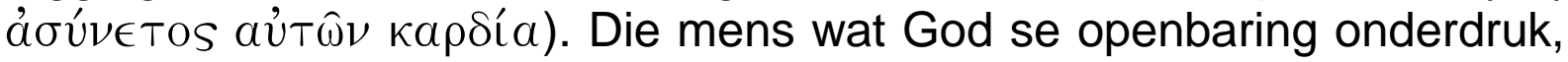
verloor ook nog die flou skynsel van die kennis van God in sy hart.

Nog 'n keer skryf die apostel dat die mens God in die algemeen ken. Die vraag is egter wat die aard van hierdie "ken" sou wees. Hierdie vraag moet des te meer gestel word in die lig daarvan dat Paulus elders van mense wat nog nie die evangelie gehoor het nie, sê dat hulle God nié ken nie.

Paulus skryf naamlik aan die Galasiërs: "Daar was 'n tyd toe julle nie vir God geken het nie en slawe was van nikswerd afgode. Maar noudat julle Hom leer ken het, of liewer, noudat Hy julle ken ..." (Gal. 4:8-9). Aan die Tessalonissense skryf hy: “... julle moenie deur hartstog en begeerte gedrywe word soos die heidene wat vir God nie ken nie" (1 Tess. 4:5). Aan die Efesiërs skryf hy: "Moenie langer soos heidene lewe nie. Hulle gedagtes lei tot niks, hulle verstand is verduister, en hulle het geen deel aan die lewe wat God skenk nie, omdat hulle hardnekkig in hulle onkunde volhard" (Ef. 4:17-18). Op grond van laasgenoemde drie teksgedeeltes is dit baie duidelik dat Paulus die mens buite Christus om kenmerk as God-onkundig. Sou dit dan beteken dat Romeine 1 'n storing (Fremdkörper), in hierdie opvatting van Paulus is? Berkhouwer (1951: 107-145) het hieroor 'n uitvoerige verduideliking gegee en hy kom tot die konklusie dat die teenstelling tussen Romeine 1 en die ander plekke 
slegs skynbaar is. Ook in Romeine 1 gaan die toorn van God oor alle goddeloosheid en ongeregtigheid van mense: "Hij (Paulus) gaat niet wijzen op een groot licht, dat ook buiten de Openbaring in Christus óm in het heidendom wordt aangetroffen" (Berkhouwer, 1951:118). Lekkerkerker (1974:68) skryf: "Er is geen grond voor een theologia naturalis die uitgaat van de religie als een algemeen gegeven in die mens en dan het specifiek-christelijke gaat maken tot een vorm van het algemeenmenslijke".

Die bedoeling van Paulus is duidelik: die heidene het God nie as God verheerlik of gedank nie. Die antwoord van die mens op God se openbaring behoort verheerliking en danksegging te wees. In plaas daarvan is die gedagtes van die mens niks (ydelheid) (Ps. 94:11).

\section{Vers 22:}

Neweskikkend tot die argument in vers 21 word die tweede argument van die rede in vers 22 tot 23 gegee. Enersyds misken die heidene God

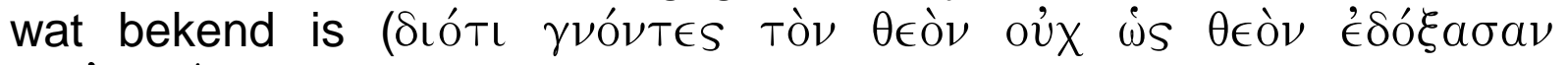

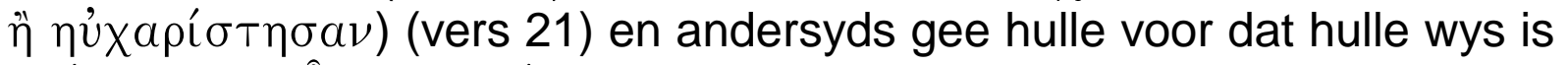

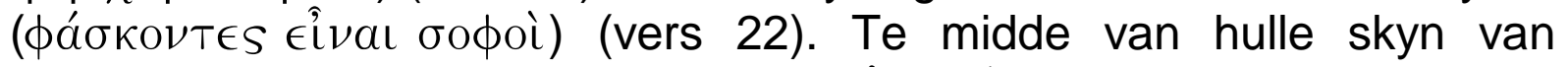

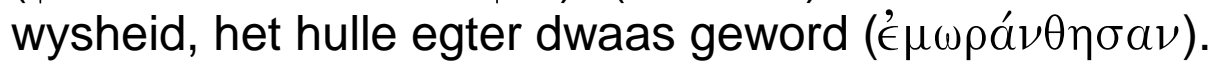

Paulus het ongetwyfeld die heidendom van sy tyd in gedagte. Die ideaal van die Griekse filosofie was die soeke na wysheid. Op 'n soortgelyke wyse stel die apostel in 1 Korintiërs 1 die dwaasheid van die prediking teenoor die vermeende wysheid van die Grieke. Deur die prediking het God die wysheid van hierdie wêreld tot dwaasheid gemaak.

\section{Vers 23:}

Epeksegeties (каi) volg die beskrywing van hulle dwaasheid waarvan vers 22 berig. In hulle onderdrukking van die kennis van God voer hulle

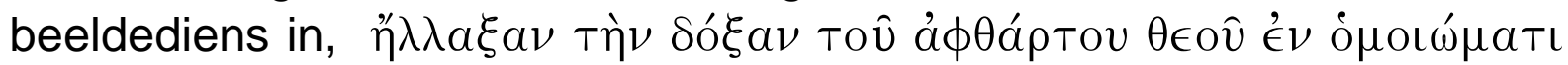

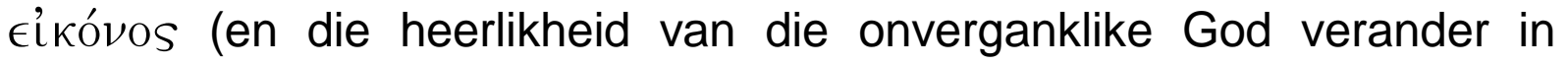
gelykvormigheid van 'n beeld). Daarna word die beeld verduidelik met 'n

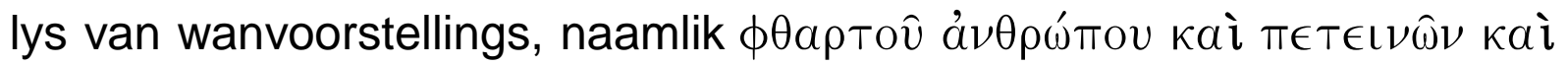
$\tau \in T \rho a \pi o ́ \delta \omega \nu$ kai é $\rho \pi \epsilon T \hat{\omega} \nu$ ('n verganklike mens [in teenstelling met God wat onverganklik is] en van voëls en van viervoetige en kruipende diere). Van God kan die mens nie wegkom nie, maar tog maak die mens van Hom allerlei verkeerde voorstellings. Paulus ontbloot hiermee die religieuse wortel van afgodsdiens. Heidense godsdienstigheid word in sy kern ontbloot as 'n dwase en verkeerde reaksie op die openbaring van God (vgl. Jonker, 1976:380). 
Die skerp oordeel van die apostel oor die heidene word in hierdie vers nader toegelig. Na die oortreding van die eerste gebod soos uiteengesit in vers 21 , beskryf hy hulle oortreding van die tweede gebod parallel daaraan in vers 22 en 23. Hulle dien die skepsels in plaas van die Skepper, 'n saak waaroor die apostel later in vers 25 uitbrei. Die merkwaardige is dat die eerste en tweede gebod blykbaar ook vir die heidene geld. Wie skepsels vereer, keer die bedoeling van Genesis 1:26 om. Die mens is na die beeld van God geskep. Goddelose mense skep God na die beeld van die mens of ander skepsels (Lekkerkerker, 1974:73).

\section{Vers 24:}

In vers 24 en 25 volg die resultaat van die heidene se onderdrukking van die waarheid soos in vers 21 en $22-23$ berig is. Dat die resultaat nou volg, blyk uit die gebruik van die voegwoord $\delta$ ı́ (daarom) waardeur hierdie gevolgsin sintakties onderskeidelik aan vers 21 en 22-23 verbind

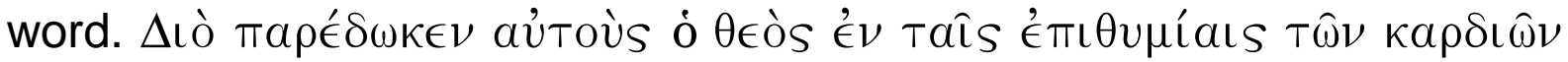

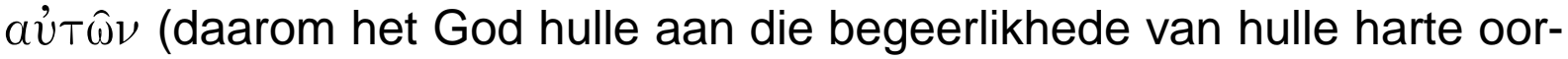

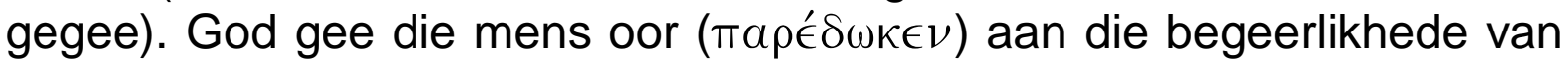
hulle harte wat die natuurlike gevolg van sy sonde is. Die woord, $\pi a \rho \epsilon ́ \delta \omega \kappa \in \nu$, word drie maal herhaal: vers 24, 26 en 28. Dit is 'n verskriklike daad van God dat Hy mense aan hulleself oorlaat. Dunn (1988:62) noem dit die "divine judgement" wat deur "divine passives" geïmpliseer word.

$\mathrm{Na}$ hierdie drievoudige gebruik van $\pi \alpha \rho \epsilon ́ \delta \omega \kappa \epsilon \nu$ volg die voorvoegsel $\epsilon$ is (aan) onderskeidelik drie maal (vers 24, 26 en 28) om aan te toon waaraan hulle oorgegee word - aan onreinheid, skandelike drifte en verdraaide opvattings. Die eerste van hierdie begeerlikhede is

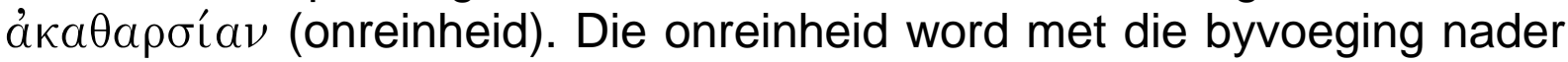

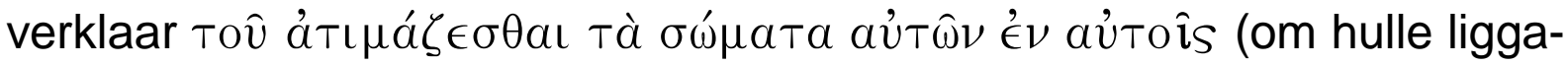
me onder mekaar te onteer). Seksuele perversiteit word by die naam genoem. Afgodery lei tot ontug. Die Wysheid van Salomo 14:12 leer dat om afgode op te rig, die begin van hoerery is. Anders gestel, kultiese onreinheid lei tot sedelike onreinheid.

\section{Vers 25:}

Vers 25 bied 'n verdere verduideliking van wie aùtoùs (vers 24) dit is wat God aan die begeerlikhede van hulle harte oorgegee het. Die relatiewe voornaamwoord olit $\nu \in S$ (diegene) verbind vers 25 as byvoeging by aU่toùs (of '́ $\nu$ aU่toîs). Dit is hulle wat die waarheid van God

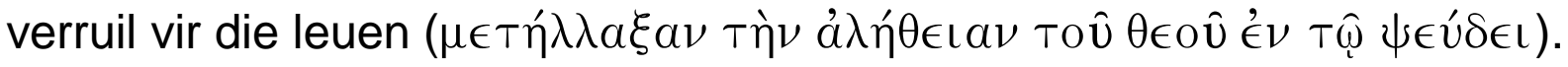


Neweskikkend noem Paulus wat noodwendig met hierdie verwerping van

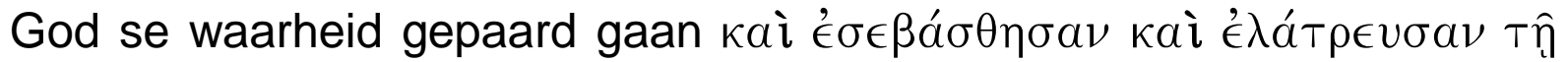

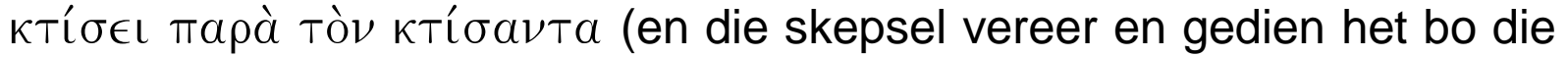
Skepper). Waar die verhouding tot God skeefgetrek en vernietig word, word menslike verhoudings ook verwring

Die laaste woorde van hierdie vers is ' $n$ relatiewe bysin (byvoeging) by

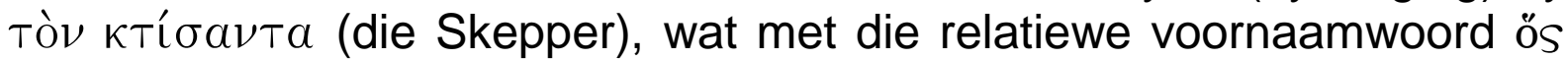

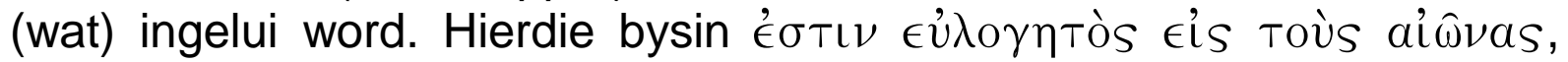
áunv (wat geprys moet word tot in ewigheid, Amen) vorm 'n plegtige lofprysing aan God, soos wat dit gebruiklik was onder die Jode wanneer die Naam van die Skepper genoem is (Dunn, 1988:64; Jonker, 1976:39). In hierdie verband aksentueer die lofprysing die afgryslikheid van die skepselverering van die heidene.

Hierdie vers gryp terug na die "liefde sonder God" (vers 24) na 'n "godsdiens sonder God" (vers 25). Die oorsprong van al hierdie probleme was dat die heidene die eerste gebod (vers 25) oortree het.

\section{Vers 26 en 27:}

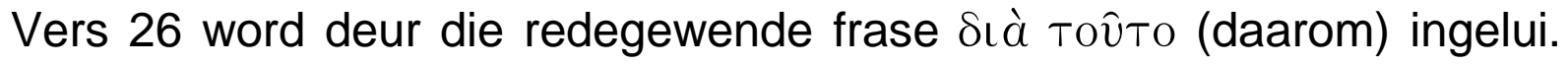
Dit sou as rede kon dien vir die voorafgaande twee verse, maar dit is meer waarskynlik dat Paulus hiermee die resultaat gee van al die verwording van die heidene, ten spyte van die feit dat God kenbaar is. Toûto verwys waarskynlik na die argumentasie van verse 19 tot 25 wat sy klimaks bereik het met die plegtige lofprysing waarmee vers 25 afgesluit het.

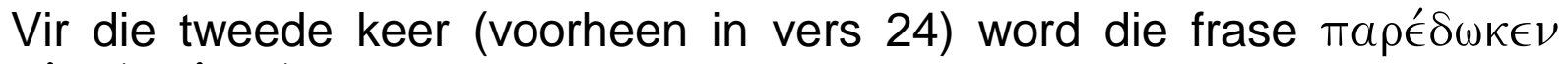

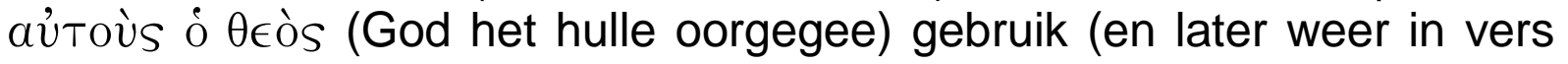
28). Daarop volg die tweede van die lys begeerlikhede van hulle harte

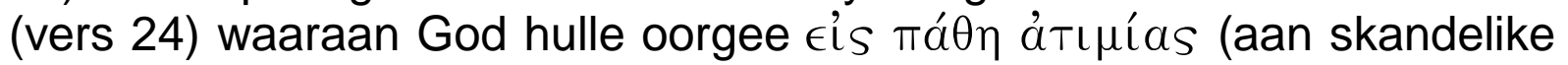
hartstogte). Die tema van seksuele perversiteit (soos in vers 24) kom hier verder aan die orde. Die apostel gaan nou meer konkreet in op wat die onreinheid van die heidene behels. In parallelle frases word

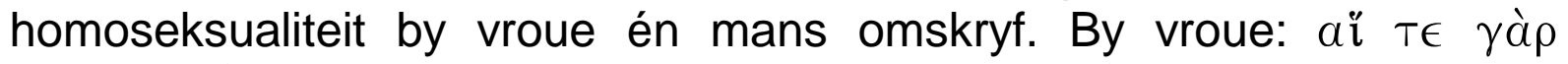

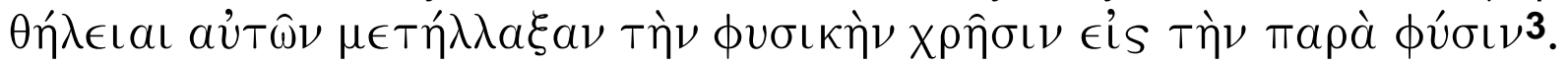

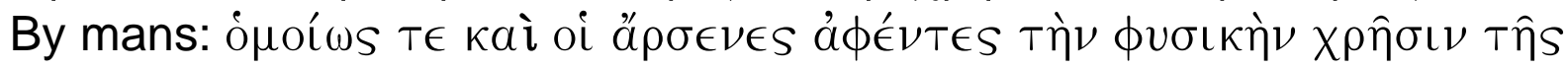

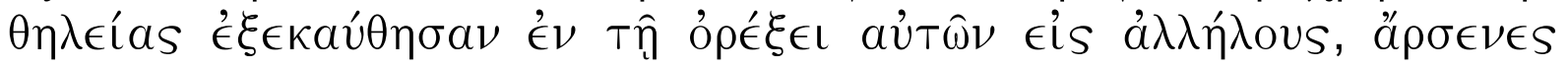

3 Want hulle vroue het die natuurlike verkeer verander in dié wat teen die natuur is (vers 26b). 


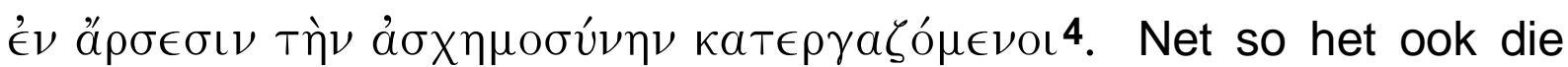
mans die natuurlike verkeer met vroue laat vaar en in hulle wellus teenoor mekaar ontbrand: manne het met manne skandelikheid bedryf (vers 27a).

Dit is opvallend hoe die woord $\mu \epsilon \tau \eta \dot{\eta} \lambda \lambda a \xi \alpha \nu$ (verander of vervang) herhaaldelik gebruik word. Wie die Skepper vervang met 'n skepsel, eindig daarmee dat natuurlike omgang van geslagte vervang word met die teennatuurlike. 5

Die resultaat van hierdie vorme van seksuele perversiteit volg daarna, ingelui met kaì (en). Aangesien die heidene hulle aan skandelike luste oorgegee het, ontvang hulle noodwendig vergelding vir hulle dwaling,

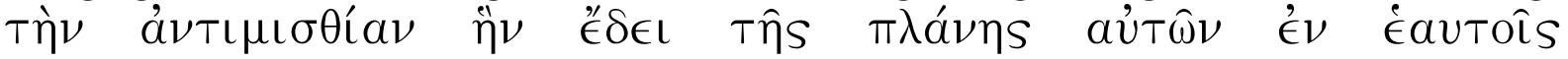

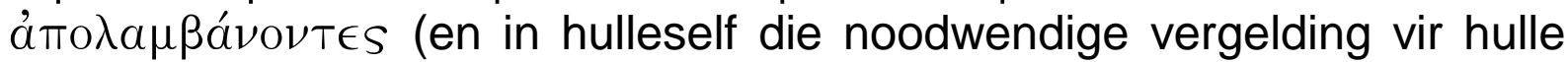
dwaling ontvang) (vers 27b).

\section{Vers 28:}

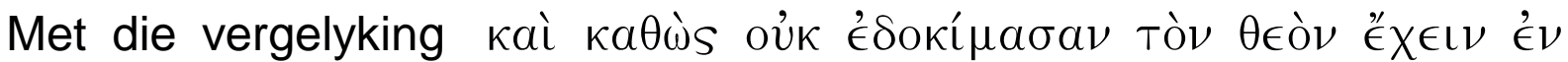

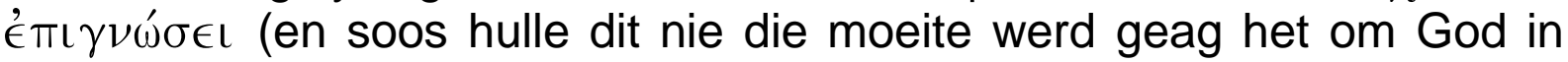
erkenning te hou nie) beklemtoon Paulus weereens die verband tussen die verwerping van die ware kennis van God en die verval van die sedelike lewe.

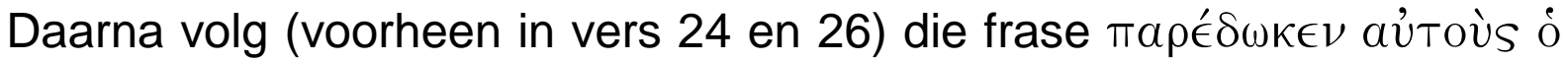
$\theta \epsilon o ̀ s$ (het God hulle oorgegee) vir die derde keer. Vir 'n derde maal word

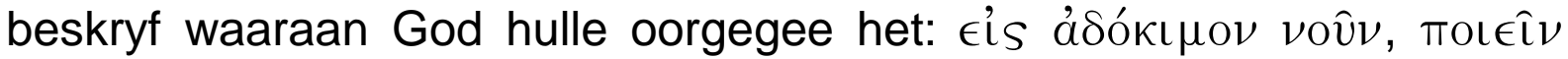

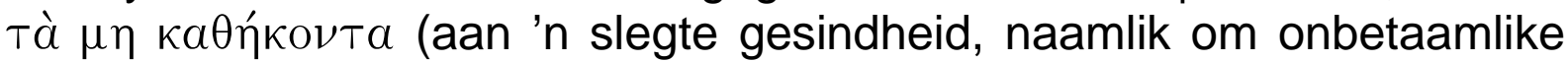
dinge te doen). God trek sy helpende hand terug en verlaat die mens. Die sonde word 'n strafmiddel. Die waardeskatting van die mens word verwerplik met die gevolg dat hy doen wat nie betaamlik is nie. "Om te doen wat onbetaamlik is", is 'n tipiese Stoïsynse uitdrukking (vgl. Lekkerkerker, 1974:78). Die feit dat Paulus by hierdie terminologie aansluit, bewys dat die Joodse leertradisie sowel as die Stoïsynse leertradisie sommige (agtergrond)gegewens bied vir die perikoop van Romeine 1:18-32. Twee kultuurpatrone word hier deur Paulus betrek.

$4 \quad$ Net so het ook die manne die natuurlike verkeer met die vroue laat vaar en in hulle wellus teenoor mekaar ontbrand: manne het met manne skandelikheid bedryf) (vers 27a).

5 Die laat-Joodse geskrif "Testament van Naftali" beskryf in hoofstuk 3 dat heidene mense is wat die goeie orde omkeer, wat hout en stene betref en uiteindelik die orde van die natuur soos wat die Sodomiete gedoen het. 


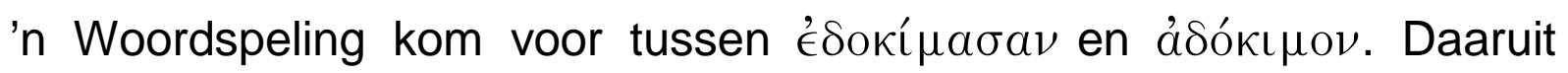
blyk dat wie dit nie die moeite werd ag om God te erken nie, oorgegee word aan dit wat nie die moeite werd is nie, naamlik 'n slegte gesindheid.

\section{Vers 29-31:}

Soos die geval was by 1:24 en 1:26 word die behandelde aùtoùs (hulle)

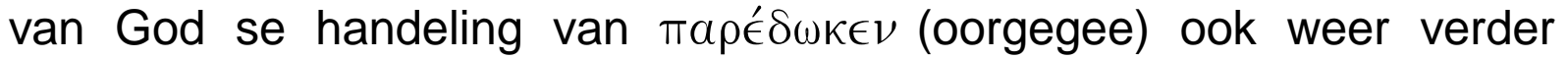
bepaal. 1:29-32 som die goddelooshede op waarvan hierdie mense vol is. God se wet word op elke punt oortree. Namate God die wêreld aan sy eie sonde oorgee, val die remminge weg en word die sedelike verval al hoe duideliker, sodat die wêreld ryp word vir die groot dag van die toorn (vgl. 2 Tim. 3:2).

Soortgelyke "sonderegisters" kom ook elders in Paulus se briewe voor, byvoorbeeld in Galasiërs 5:19 e.v. Blykbaar is daar nie orde in hierdie register vas te stel nie - "De zonde is wanordelijk" (vgl. Lekkerkerker, 1974:79).

\section{Vers 32:}

Die sintaktiese verband van 1:32 met die voorafgaande verse toon aan dat diegene wat so vervul is met die boosheid $(1: 29-31)$ diegene is wat God aan hulle slegte gesindheid oorgegee het (1:28). Op so 'n manier kom Paulus tot 'n konklusie. Romeine 1:32 word met die betreklike voornaamwoord oÏTIVÉS (hulle wat) ingelui. In hierdie betreklike bysin toon Paulus dat hierdie mense die goddelose dinge teen hulle beterwete in doen. Paulus gaan daarvan uit dat ook die heidene sónder God se besondere openbaring 'n besef het van die verordeninge van God. Hulle behoort te besef dat sodanige optrede aanleiding gee tot die verval van 'n samelewing, tot ondergang en die dood. Daarbenewens verdien diegene, wat sulke dinge doen, die dood. Ook in die heiden spreek daar 'n gewete (vgl. Rom. 2:15).

\subsection{Gevolgtrekking}

Die hele perikoop (1:18-32) dien as uitgebreide motivering waarom ook die heidenwêreld ' $n$ dringende behoefte het aan die evangelie. Die heidene is goddeloos ten spyte daarvan dat hulle 'n besef het van God se verordeninge. God se toorn word geopenbaar oor die goddeloosheid en ongeregtigheid soos Paulus dit geskilder het. Dit is waarom hy gedronge voel om die boodskap in Rome te gaan verkondig (1:15).

\section{Stilistiese patrone}

'n Aantal stylpatrone is waarneembaar. 


\section{- Want}

Die rà $\rho$ (want) waarmee 1:18 begin, is die vierde in die reeks wat klimakties uit die stelling van 1:15 voortvloei.

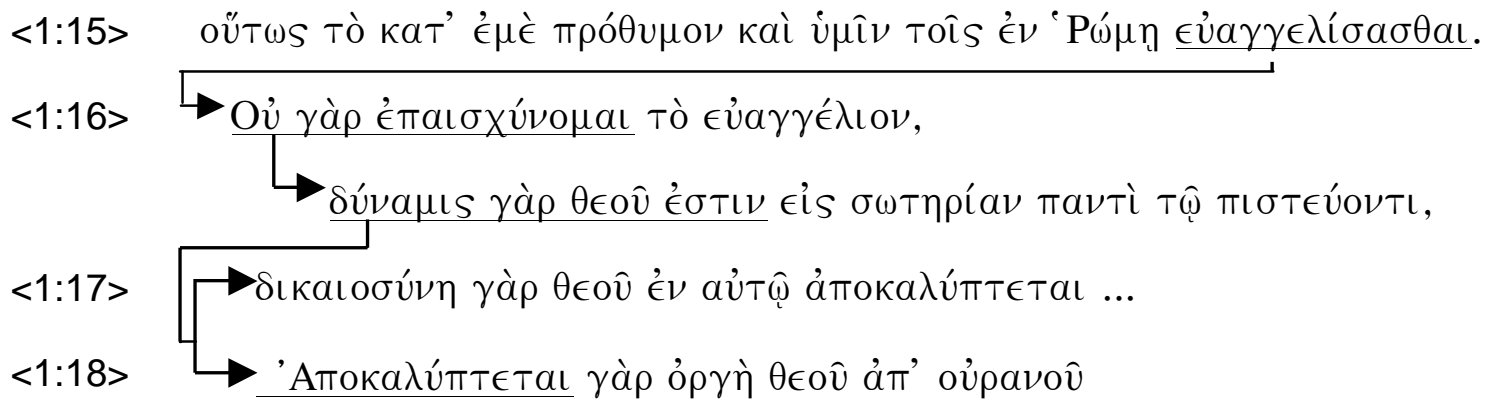

Die redegewende bepalings bou op tot 'n klimaks met die inleiding tot die perikoop 1:18-32 om die noodsaak van die evangelie te beklemtoon.

\section{- Kontrasterende redes}

Die redes in 1:17 en 1:18 staan in skerp kontras met mekaar, albei ingelui met $\gamma a ̀ \rho$. Die kontras word verskerp deur die parallelle, maar

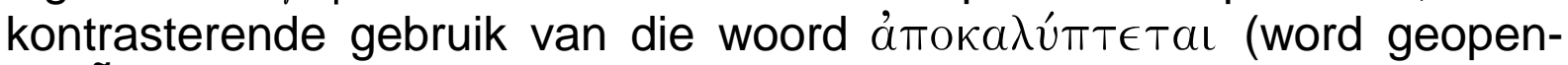
baar)

\section{- Omdat}

Die redegewende voegwoord SıóTı (omdat) lui twee parallelle redes (1:19-20 en 1:21-23) in om weer te gee waarom God se toorn geopenbaar word (vers 18). Die verse moet as dubbelvoudige rede gelees word waarom God sy toorn openbaar. Ten spyte daarvan dat God kenbaar is (1:19-20), erken hulle Hom nogtans nie (1:21-23).

\section{- Ken en voorgee}

Hierdie "nogtans nie"-deel van die rede $(1: 21-23)$ val in twee parallelle dele uiteen (vers 21 en 22-23). Die twee deelwoorde ( $\gamma \nu$ ó $\nu T \in S$ en $\phi a ́ \sigma \kappa о \nu T \epsilon S$ ) (terwyl hulle ken en voorgee) staan neweskikkend ten opsigte van mekaar. Hierdie twee parallelle frases staan antiteties teenoor mekaar en impliseer: hulle (dit wil sê die heidene) ken God, maar gee voor om beter te weet deur die waarheid te verander. 


\section{- Vervang}

Die herhaaldelike gebruik van die werkwoord $\alpha \lambda \lambda \alpha \alpha^{\sigma} \sigma \omega \omega$ is opvallend. In Romeine 1:23 ( $\lambda \lambda \lambda \alpha \xi \alpha \nu$ - hulle het die majesteit van God vervang), in 1:25 ( $\mu \epsilon \tau \eta ́ \hat{\lambda} \lambda \alpha \xi \alpha \nu$ - hulle het die waarheid van God vervang). In 1:26 weer ( $\mu \epsilon \tau \eta ́ \hat{\eta} \lambda \alpha \xi \alpha \nu$ - hulle het die natuurlike seksuele omgang vervang met die teennatuurlike). Wie die majesteit en waarheid van God vervang, eindig daarmee dat hulle ook die natuurlike seksuele omgang vervang met die teennatuurlike.

\section{- God het hulle oorgegee}

Die herhaaldelike gebruik van $\eta \lambda \lambda a \xi \alpha \nu$ pas by die herhaaldelike gebruik

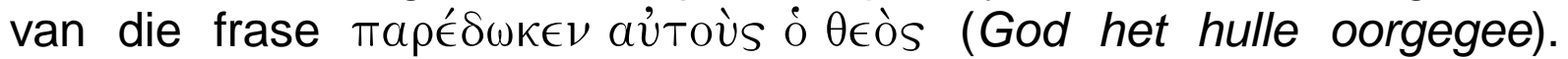
Hierdie frase word drie keer gebruik (1:24; 26 en 28), elke keer met 'n redegewende woord of frase. Daarna volg 'n woord of frase wat omlyn. Die "hulle" in elke frase word ook telkens verder beskryf. Hierdie drievoudige herhaling toon 'n klimaktiese opbou. In die derde frase word die verwording van "hulle" met 'n opstapeling van allerhande ongeregtigheid tot 'n klimaks gedryf. God het hulle oorgegee aan wat hulle begeer het en hulle daarin laat bly. So het Hy hulle die uitoefening van sy toorn oor hulleself laat voltrek. Meer nog, hulle het vasgevang geraak in 'n bose sirkel: omdat hulle God nie as God erken en geëer het nie, het Hy hulle aan hulle perverse, ontmenslikende begeertes oorgegee. Juis hulle doen van hierdie dinge het hulle opnuut skuldig gemaak aan God se oordeel; daarom verdien hulle die dood (vers 32). Al het hulle hulleself met alles wat hulle gedoen het, van God probeer losmaak, kon hulle hulle self nie losmaak van hulle aanspreeklikheid voor God nie. Hulle het aan God skuldig gebly. Die uiteinde is pateties: hulle het God in eiesinnigheid probeer ontgoddelik, maar in plaas daarvan het hulle hulleself ontmenslik.

Uit die stilistiese patrone word die absolute verlorenheid van die heidene beklemtoon. Juis hierdeur word die absolute behoefte aan die evangelie beklemtoon. 


\section{Gedagtestruktuur}

\subsection{Ontleding}

\section{Hoofmededeling: $(1: 14-15)$}

Ek staan onder verpligting teenoor almal, met die gevolg dat ek ook aan julle in Rome die evangelie wil verkondig (1:15)

Om watter rede(s) wil Paulus die evangelie verkondig?

Want ek skaam my nie oor die evangelie nie ... want dit is ' $\mathrm{n}$ krag tot redding vir elkeen wat glo ...

\section{Om watter rede(s) is dit ' $\mathrm{n}$ krag tot redding?}

Want die geregtigheid van God word daarin geopenbaar uit geloof en tot geloof ...

Want die toorn van God word geopenbaar ...

(1:18c) Waaroor is God vertoornd? (Die rede vir sy toorn)

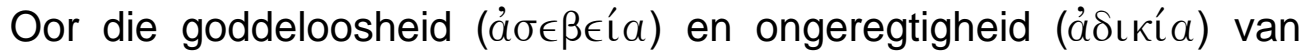
mense

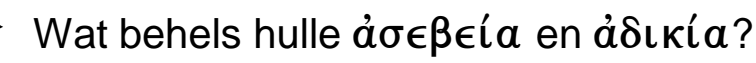

Hulle onderdruk die waarheid.

$(1: 19-23)$

Waarom openbaar God sy toorn?

Dit is vir almal moontlik om die waarheid te ken

Want die kenbare/kennis (Tò $\gamma \nu \omega \sigma \tau o ́ \nu$ ) van God is aan hulle geopenbaar

Hoe is dié kennis kenbaar ( $\gamma \nu \omega \sigma \tau o ́ v)$ ?

God het dit aan hulle geopenbaar

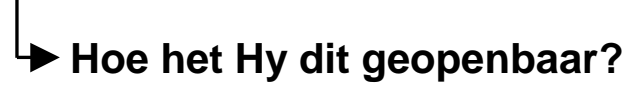

- Hoewel die dinge aangaande God onsigbaar is,

- word dit verstaan en gesien

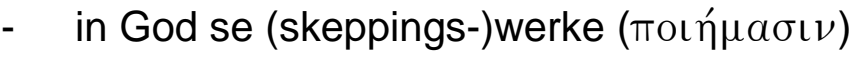

- van die skepping van die wêreld af.

Wat is die kenbare dinge van God?

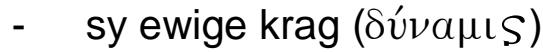

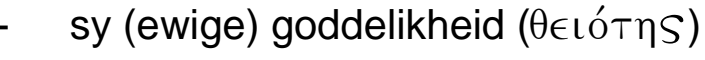


Watter implikasie het dit vir diegene wat die waarheid onderdruk?

Gevolglik het hulle geen verontskuldiging (àvatто入оүท́тоus) nie.

(b) Daarbenewens het hulle, terwyl hulle voorgee dat hulle wys is, dwaas geword.

In weerwil daarvan dat hulle God (kan) ken

- het hulle Hom nie as God geëer of gedank nie.

- Inteendeel: Hulle het dwaas geword en hulle hart is verduister

Deurdat hulle sy heerlikheid vervang het met verganklike skepsels

Wat het hulle gedoen om dit te verdien? (Teruggryp op 1:21-23)

Hulle het

- God se waarheid verruil vir die leuen

- en mense gedien en geëer in plaas van die Skepper.

Lofprysing:

Hy moet geprys word tot in ewigheid 
$(1: 26)$

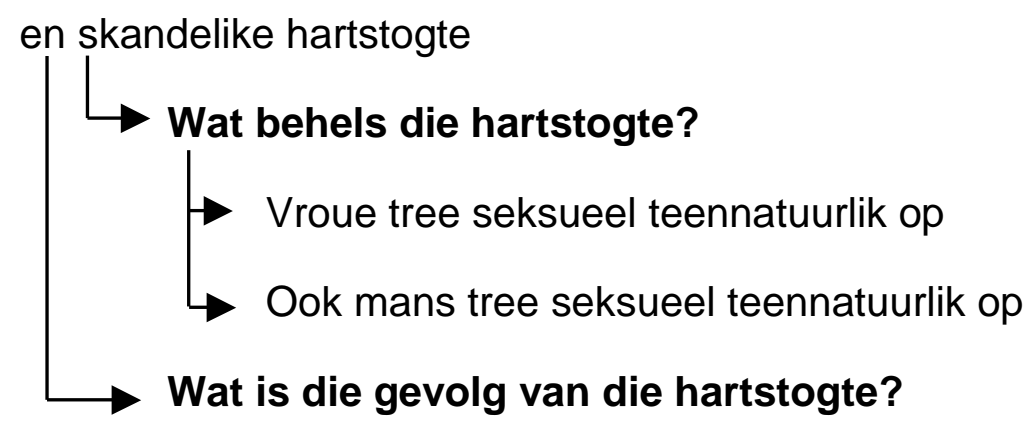

Hulle moet vergeld word vir hulle dade

\section{Waarom het God hulle nou weer oorgegee?}

Hulle wou God nie erken nie

en aan slegte gesindheid om te doen wat onbetaamlik is-

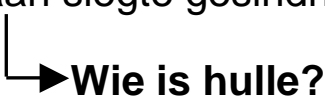

Diegene wat vol is van allerhande ongeregtighede

In die geheel van die voorafgaande beskrywing gesien, is dit diegene wat die waarheid ken, maar nogtans die verkeerde doen - daarom is hulle doodskuldig!

\subsection{Kommentaar}

In vers 15 word die hoofmededeling gemaak: Paulus wil na Rome gaan om die evangelie te verkondig. By wyse van 'n ketting "want"-sinne gee Paulus in verse 16-18 die redes waarom hy die evangelie wil verkondig.

Die laaste van hierdie "want"-sinne staan in vers 18 : "want" die toorn van God word geopenbaar. Die stelling in vers 18 word dan verder begrond in die daaropvolgende verse. Eers word beskryf waaroor God vertoornd is (vers 18c) en daarna volg die redes waarom God sy toorn openbaar (vanaf vers 19). Dit is vir almal moontlik om die waarheid te ken (vers 19-20), maar nogtans het hulle die waarheid onderdruk (vers 21-31). Vers 32 bied 'n samevatting en slot.

Vers 19 tot 20 verduidelik waarom dit vir almal moontlik is om die waarheid te ken. Paulus verduidelik dat die kenbare van God aan die mense geopenbaar is (vers 19b) en hoe dit geopenbaar is (vers 19b) en wat geken kan word (vers 20). Hierdie entumemiese argument (vgl. Moores, 1995:46) bring Paulus dan by 'n gevolgtrekking wat die kernpunt van sy argument vorm: almal was veronderstel om God te ken. Hulle 
erken Hom egter nie; gevolglik is almal sonder verontskuldiging (vers 20c).

Vers 21 tot 31 brei verder uit oor hoe die mense, ten spyte daarvan dat hulle veronderstel was om God te ken, die waarheid onderdruk het. Vers 22 en 23 beskryf die tweevoudige manier waarop die mense die waarheid in praktyk onderdruk het. Vers 24 tot 31 bied die resultaat van hulle optrede deur te wys op die drievoudige reaksie van God: God gee hulle oor aan die begeerlikhede van hulle harte (vers 24c-25), hulle skandelike hartstogte (vers 26-27) en slegte gesindhede (vers 28-31). Opvallend is die driemalige herhaling van "God het hulle oorgegee". Hierdie eenheid word afgesluit met 'n onbetwisbare samevattende gevolgtrekking in vers 32 - hulle verdien die dood!

Binne die beskrywing dat God die mense oorgegee het aan die begeerlikhede van hulle harte (vers 24c-25), is vers 25 'n teruggryp na die argument van vers 21 tot 23 (hulle het die waarheid vir die leuen verruil). Met vers 28 word weer teruggegryp na vers 19 tot 20, naamlik dat hulle God nie erken nie.

Porter (1994) maak 'n retoriese analise van Romeine 1:18-32 wat hy as epideiktiese6 ${ }^{6}$ diskoers identifiseer (Porter, 1994:215). In plaas daarvan dat nuwe en revolusionêre waardes gepropageer word, verdedig die epideiktiese diskoers tradisionele waardes. 'n Beroep word op universele waardes gemaak om die gehoor daarmee tot ander insigte te bring.

Die patroon van die epideiktiese diskoers bevestig die gedagtestruktuur soos hierbo uiteengesit:

- Romeine 1:18 vorm die exordium (inleiding). Die aandag van die gehoor word gewek deurdat die onderwerp aangekondig word - die oordeel van God wat uit die hemel geopenbaar word.

- Daarna volg die narratio (uiteensetting van die inligting) in Romeine 1:19-21). Bondig, helder en geloofwaardig word die argument gestel deur 'n beroep te doen op die oortuigings van die gehoor (entumemiese argumente).

- In Romeine 1:22-31 volg die divisio (die skeiding) waarin die onvanpaste optrede van mense gesensureer word. By wyse van drie parallelle onderafdelings $(22-24 ; 25-27 ; 28-31)$ word uitgebrei op die

6 Binne die Hellenistiese retoriek word daar tussen drie tipes diskoers onderskei:

- Forensies: beskuldiging of verdediging in regspleging.

- Deliberatief: aanmoediging of afraai van 'n samekoms vir toekomstige optrede.

- Epideikties: prys of blameer 'n gemeenskap in seremoniële konteks. 
stellings van die narratio $(1: 19-21)$ deur te beskryf wat die goddelose en slegte mense gedoen het met hulle verhouding tot God. Dit word gevolg met die aankondiging dat God hulle oorgegee het en word gekonkludeer met ' $n$ beskrywing van die toestand waarin hulle oorgelewer is.

- Romeine 1:32 vorm die conclusio (konklusie) van die diskoers wat 'n kort samevatting bied met 'n appèl tot 'n goddelike orde oor die aangeleentheid.

\subsection{Gevolgtrekking}

Op grond van hierdie gedagtegang word dit duidelik waarom Paulus dit noodsaaklik ag om die evangelie in Rome te gaan verkondig. Die rede is dat hierdie evangelie vir elkeen wat dit glo, redding kan bring. 'n Mens kan net deur te glo, gered word. Daarom is die evangelie ook dringend noodsaaklik vir diegene oor wie God se toorn kom. Hy gebruik blykbaar die entumemiese oorredingstegniek van die Hellenistiese retoriek. Die tipe argumente wat hy gebruik, sluit aan by die oortuiging van sy gehoor, om sodoende met groter trefkrag te redeneer. God se toorn kom oor diegene wat veronderstel is om Hom as God en Skepper te ken en te vereer, maar dit nogtans nie doen nie. Daaroor moet sy gehoor immers saamstem. Die goddelose mense het daarom die redding van Christus dringend nodig. Die evangelie moet aan hulle verkondig word, sodat hulle tot geloof kan kom.

Die logika agter Paulus se gedagtegang is duidelik. Niks verhinder mense méér daarvan om by Christus uit te kom, as hulle onvermoë om te besef dat hulle Hom nodig het, of die onwilligheid om dit te erken nie. Om dit moontlik te maak om te verduidelik dat verlossing beskikbaar is vir Jode en heidene, moet Paulus eers bewys dat albei groepe 'n dringend behoefte daaraan het. Paulus bespreek nie-Jode en Jode onderskeidelik. In elkeen se geval is Paulus se gedagtegang dieselfde. Hy begin deur hulle te wys op hulle kennis van God en van sy goedheid. Daarna konfronteer hy hulle met die feit dat hulle nie ooreenkomstig hierdie kennis lewe nie - inteendeel, hulle het hierdie kennis doelbewus onderdruk en selfs weerspreek deur hulle goddelose lewenswyse. Daarom is hulle onverskoonbaar skuldig voor God. Niemand kan onskuldig pleit nie, want niemand kan beweer dat hy onwetend was nie.

\section{Samevattende gevolgtrekking}

Met die Romeine-brief wil Paulus beskryf dat 'n mens alleen uit genade gered kan word. Die genade kom daarop neer dat, hoewel almal skuldig is tot die dood, hulle deur die geloof in Jesus Christus vrygespreek kan word. Romeine 1:18-32, as deel van 'n groter deel, naamlik Romeine 
1:18-3:20, het 'n belangrike funksie binne sy argumentasie. 'n Mens kan alleen 'n begrip kry van die onuitspreeklike grootheid van God se genade as jy onder die indruk gebring word van die mense se situasie vóór hierdie heilsdaad. Alleen teen die agtergrond van die reddeloosheid van die mensheid voor en sonder Christus, kan ' $n$ mens iets verstaan van wat God se genade werklik inhou. Daarom was dit noodsaaklik dat Paulus hierdie skokkende waarheid skilder, en daarom sy betoog oor die patetiese toestand van sowel nie-Jode (1:19-32) as Jode (2:1-3:20).

Nog ' $n$ belangriker oogmerk is om hiermee die noodsaak van geloof volgens die evangelie te beklemtoon. Paulus wil nie alleen nie-Jode en Jode van hulle sonde en strafwaardigheid oortuig nie, maar ook van die dringendheid dat hulle positief op die evangelie moet reageer. Hoewel die leser hierdie betoog as negatief en verdoemend mag ervaar, is dit nie die bedoeling nie. In die belang van sowel nie-Jood as Jood en in die lig van die nuwe situasie van die Christusgebeure, was dit onvermydelik dat die saak tot die been toe oopgevlek word. Alleen dan kan Romeine 3:21 en volgende verse reg verstaan word. Terwyl Romeine 1:18-3:20 die oordeel van God omvattend beskryf, is die bedoeling daarvan om die mense ontvanklik te maak vir die evangelie van Jesus Christus. Soos daar in Romeine 1:18-3:20 gesê word dat almal, sonder onderskeid, strafwaardig is, net so word in Romeine 3:22 en die volgende verse gesê dat almal, sonder onderskeid, gered sal word as hulle in Jesus Christus glo.

Om dan terug te kom by die vraagstuk aan die begin gestel oor die verhouding tussen die kennis van God en sy skeppingsopenbaring volgens Romeine 1:18-32 is die volgende baie duidelik: God het Hom in sy skepping en handelinge as God betuig en kenbaar gemaak. Die destydse heidense godsdienste en filosofieë bied bewyse van 'n bewussyn van 'n god. Paulus sluit in Romeine 1, waarskynlik met 'n epideiktiese retoriese benadering deur middel van 'n entumemiese argument by daardie kennis aan, maar sê niks meer nie. Hier staan niks daarvan dat heidene saligmakende kennis besit nie - inteendeel! Talle studies oor hierdie vraagstuk het dit al uitgewys.

Dit is uiters belangrik om te let op die funksie van hierdie uitsprake as deel van Paulus se betoog. Paulus wil bloot bewys dat hierdie mense geen verontskuldiging het nie. Om hieruit af te lei dat Paulus die opvatting huldig dat daar so iets as saligmakende Godskennis naas die Woordopenbaring is, is 'n oorspanning van die teks. Dit het ook geen sin om te spekuleer oor wat sou gebeur indien die nie-Jode destyds positief sou gereageer het op die selfbekendmaking van God in sy skepping en onderhouding nie. Die feit is dat hulle eenvoudig nié so gereageer het nie. Dit het net so min sin om vanuit die konteks van hierdie teks te 
spekuleer oor watter moontlikhede daar vandag vir so 'n positiewe reaksie kon wees. Dit is onmoontlik om uit Romeine 1 af te lei dat Paulus van oordeel sou wees dat daar 'n ander heilsopenbaring is as deur die evangelie (naamlik geregtigheid deur Jesus Christus deur geloof in Hom) en 'n ander weg tot redding as om die evangelie te glo nie.

\section{Bibliografie}

BAAIJ, P.K. 1998. De God antwoordende mens. Exegetische studie van Romeinen 3:21-8:39. Heerenveen : Groen.

BARTH, K. 1968. The epistle to the Romans. London : Oxford University Press.

BERKHOUWER, G.C. 1951. De algemene openbaring. Kampen : Kok.

BORNKAMM, H. 1948. Luther und das Alte Testament. Tübingen : Mohr.

CALVIN, J. 1849 [1539]. Commentaries on the Epistle of Paul the apostle to the Romans. (Tr. Owen, J.) Edinburgh : Calvin Translation Society.

CALVYN, J. 1957 [1559]. Institutie. (Vert. Sizoo, A.) Delft : Meinema.

COETZEE, J.C. 1986. Die gedagtestruktuur (-lyn) van Romeine. (In Coetzee, J.C., red. Glo - en jy sal lewe. Die brief aan die Romiene - vir preeklees en Bybelstudie. Orkney : EFJS. p. 6-13.)

COETZEE, J.C. 1988. Gedagtestruktuurontleding en die eksegese van die Heilige Skrifte. (In Coetzee, J.C., red. Koninkryk, Gees en Woord. Pretoria : NG Kerkboekhandel. p. 19-37.)

COOK, J.G. 1994. The logic and language of Romans 1:20. Biblica, 75(4):494-517.

DUNN, J.D.G. 1988. Word biblical commentary. Volume 38A. Romans 1-8. Dallas : Word Books.

DU TOIT, A.B. 1989. Geregverdig uit geloof: Romeine 1:16-17. (In Vorster, W.S. \& Engelbrecht, A.S., reds. Uit genade alleen? Opstelle oor Romeine. Pretoria : Universiteit van Pretoria. p. 15-21.)

FLOOR, L. 1982. Perspektiewe op die prediking van Paulus. Pretoria : NG Kerkboekhandel.

GREIJDANUS, S. 1933. De brief van den apostel Paulus aan de gemeente te Rome. Kommentaar op het Nieuwe Testament. Amsterdam : Bottenburg.

GUNNING, J.H. 1868. Blikken in de Openbaring II. Amsterdam : Hover.

JANSE VAN RENSBURG, J.J. 1980. Die ontleding van sintaktiese struktuur in die Griekse Nuwe Testament. Die ontwerp van 'n metode, geillustreer met Romeine 8. Potchefstroom : PU vir CHO. (Th. D.-proefskrif.)

JORDAAN, G.J.C. 1988. 2 Petrus 1:19, 21 in die lig van gedagtestruktuuranalise. (In Coetzee, J.C., red. Koninkryk, Gees en Woord. Pretoria : NG Kerkboekhandel. p. $70-80$.)

JONKER, W.D. 1967. Die brief aan die Romeine. Kaapstad : NG Kerk-Uitgewers.

KRUGER, M.A. 2000a. Commentary on Romans. Clubview : Benedic Books.

KRUGER, M.A. 2000b. The Kingdom of God and those who have not heard the contents of Scripture. Voordrag by die Gereformeerde Teologiese Kongres te Potchefstroom, Augustus 2000.

LEKKERKERKER, A.F.N. 1974. De brief van Paulus aan de Romeinen I. Nijkerk : Callenbach.

LUTHER, M. 1927 [1515/16]. Vorlesung über den Römerbrief. München : Kaiser Verlag.

MICHAELIS, W. 1978. opaw. (In Friedrich, G., ed. Theological dictionary of the New Testament. Volume V. Grand Rapids : Eerdmans. p. 315-381.) 
MOORES, J.D. 1995. Wrestling with rationality in Paul. Romans 1-8 in a new perspective. London : Cambridge University Press.

MORRIS, L. 1992. The epistle to the Romans. Michigan : Eerdmans.

OWEN, H.P. 1959. The scope of natural revelation in Rom. 1 and Acts 17. New Testament Studies, 5:133-143.

PELSER, G.M.M. 1989. Die betekenis en funksie van Romeine 1:18-3:30. (In Vorster, W.S. \& Engelbrecht, A.S., reds. Uit genade alleen? Opstelle oor Romeine. Pretoria : Universiteit van Pretoria. p. 29-54.)

PORTER, C.L. 1994. Romans 1:18-32: The role in the developing argument. New Testament Studies, 40:210-228.

RIDDERBOS, H. 1959. Aan de Romeinen. Commentaar op het Nieuwe Testament. Kampen : Kok.

SANDAY, W. \& HEADLAM, A.C. 1902. A critical and exegetical commentary on the epistle to the Romans. Edinburgh : Clark.

STOTT, J. 1994. Romans - God's good news for the world. Downers Grove : Intervarsity Press.

TESTAMENT OF NAPHTALI. 1983. (In Charlesworth, J.H., ed. The Old Testament pseudepigrapha. Volume 1. London : Darton, Longmon \& Todd. p. 810-814.)

VILJOEN, F.P. 2001. Song and music in the Pauline epistles. Paul's utilisation of Jewish, Roman and Greek musical traditions to encourage the early Christian communities to praise God. In die Skriflig, 35(3):423-442.

VON CAMPENHAUSEN, H.F., ed. 1957. Die Religion in Geschichte und Gegenwart. Handwörterbuch für Theologie und Religionswissenschaft. Erster Band. Tübingen : Mohr.

WISDOM OF SOLOMON. 1983. (In Charlesworth, J.H., ed. The Old Testament pseudepigrapha. Volume 1 \& 2. London : Darton, Longmon \& Todd. p. 935988.)

YOUNG, R.A. 2000. The knowledge of God in Romans 1:18-23: exegetical and theological reflections. Journal of the Evangelical Theological Society, 43(4):695-707.

\section{Kernbegrippe:}

Godskennis

Godsopenbaring

natuurlike teologie

Romeine 1:18-32

skeppingsopenbaring

\section{Key concepts:}

creational revelation

knowledge of God

natural theology

revelation of God: the nature of

Romans 1:18-32 